\title{
An outbreak of meningitis associated with E.C.H.O virus type 9
}

\author{
C. R. NEWMAN ${ }^{1}$ AND R. B. F. SMITH ${ }^{2}$ \\ From the Royal Air Force Hospital, Wegberg, Germany, and \\ the Virus Diagnostic Laboratory, Central Public Health Laboratory, \\ Colindale, London
}

SYNOPSIS This paper describes an outbreak of aseptic meningitis associated with E.C.H.O virus type 9 among members of the Royal Air Force and their families stationed in western Germany 1961. There was a total of 44 cases. Epistaxis occurred in eight cases and in 16 there was a ras? Virus was isolated from faeces in 11 of 24 cases examined and from cerebrospinal fluid in three out of six.

The association of E.C.H.O virus type 9 with aseptic meningitis accompanied by a rash is now well known (Tyrell, 1958; Sabin, Krumbiegel, and Wigand, 1958; Lyle, 1959). We should like to record a further outbreak of such an illness in which epistaxis was a prominent feature. Cases occurred during July and August, 1961, over a period of 32 days at a Royal Air Force station in western Germany.

The station is a large one with a population of approximately 3,000 including both Service personnel and their families living in married quarters within the station boundary. Although the station is almost entirely self-contained, there is free mixing between the station population, Service personnel and their families at other stations, and the local civilians.

There was a total of 44 cases, of which $36(87 \%)$ were in children; the remainder were in all but one instance in parents of affected children. The overall age distribution is shown in Figure 1. Fresh cases tended to appear at intervals of 48 hours (Fig. 2). The majority occurred in a geographically limited area of married quarters, and only three affected children lived outside the station; two attended the station school and the third was the 3-year-old sister of one of these.

The local German public health authorities reported no similar illness in the civilian population though there was an epidemic of paralytic poliomyelitis at about the same time in the vicinity.

${ }^{1}$ Now at Royal Air Force Hospital Wroughton, Swindon, Wilts. ${ }^{2}$ Now at Hunton Hall, Medical College of Virginia, Richmond, 19, V.A., U.S.A.

Received for publication 12 February 1964.
Unfortunately no details as to virus studies were obtainable. No similar cases were seen at any othe Royal Air Force station, nor did any case occur among the staff who attended those admitted hospital.

All the children involved, apart from a few youn ones who were family contacts of cases, had made frequent use of the station swimming pool and adjoining paddling pool. The swimming pool wक्ष supplied with water which passed through a $\cos$ tinuous chlorination plant but the paddling pool was filled separately from an unchlorinated water suppl:

CLINICAL FEATURES

Symptoms and signs are set out in Table I. Seven cases were admitted to hospital; the first three before the natufe of the epidemic was appreciated and the remaining four because of an unusually severe or prolonged illness.

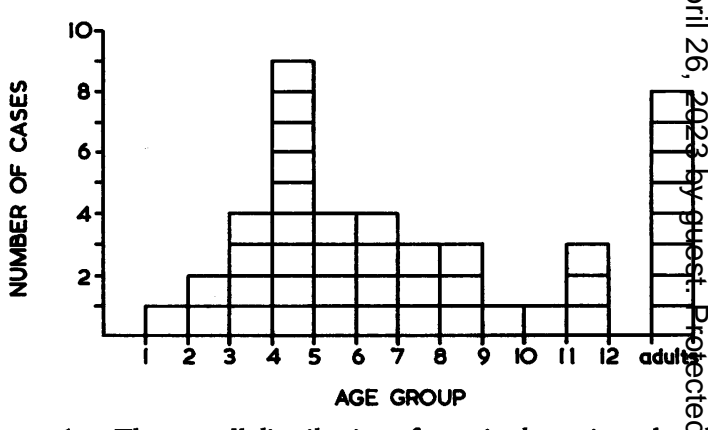

FIG. 1. The overall distribution of ages in the series related to the number of cases. 


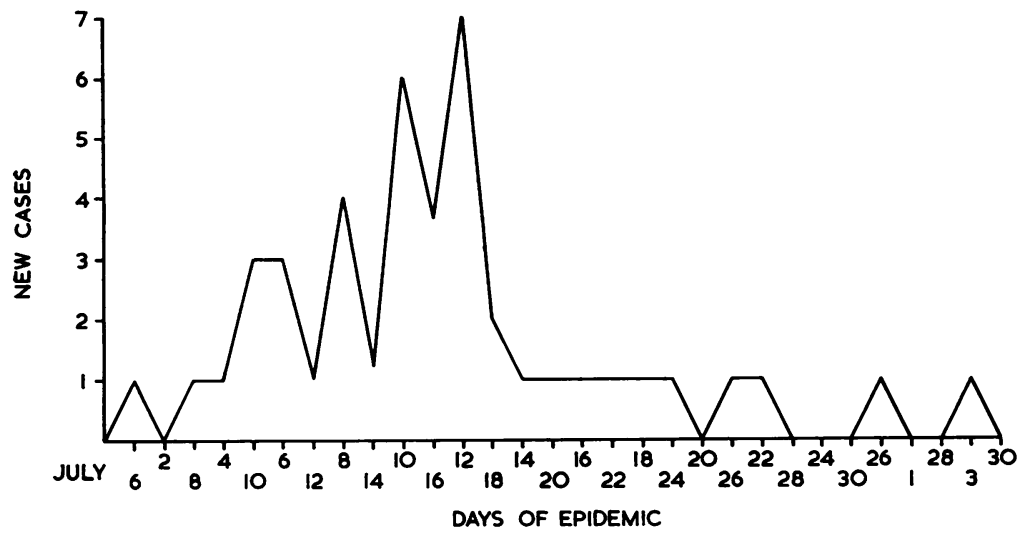

FIG. 2. Graph showing the time pattern of the epidemic.
TABLE I

INCIDENCE OF SYMPTOMS AND SIGNS IN 44 CASES

\begin{tabular}{llll} 
Symptom & No. of Cases & Sign & No. of Cases \\
\hline Headache & $44(100 \%)$ & Pharyngitis & $36(81 \%)$ \\
Nausea & $32(72 \%)$ & Neck rigidity & $27(61 \%)$ \\
Vomiting & $32(72 \%)$ & Drowsiness & $22(50 \%)$ \\
Anorexia & $32(72 \%)$ & Rash & $16(36 \%)$ \\
Lethargy & $27(61 \%)$ & Adenopathy & $11(25 \%)$ \\
Abdominal pain & $15(34 \%)$ & Epistaxis & $8(13 \%)$
\end{tabular}

Prodromal symptoms were of extremely short duration or non-existent, most illnesses starting with a headache of rapidly increasing intensity and pyrexia up to $104^{\circ} \mathrm{F}$. $\left(40^{\circ} \mathrm{C}\right.$.). Eight of the 44 patients $(18 \%)$ had epistaxis in the early stages of the illness, being in one case severe enough to require nasal packing. The illness lasted from 48 to 72 hours in children, after which most had completely recovered, though a single relapse occurred in six of the 44 cases $(13 \%)$. In adults the disease ran a more prolonged course of up to seven days, and nausea and vomiting in contrast to abdominal pain were more frequent and severe.

A diffuse maculo-papular rash mainly on the face, shoulders, and chest was observed in 16 of the 44 cases $(36 \%)$. A petechial eruption was seen on the soft palate in one case. The throat was inflamed without an exudate.

Moderate enlargement of the lymph glands was observed in all patients admitted to hospital. The enlarged glands were located mainly in the cervical and axillary regions; they were soft, but not tender. Splenomegaly was found in association with glandular enlargement in four cases $(9 \%)$.

\section{LABORATORY INVESTIGATIONS}

Only a proportion of patients was investigated because of the difficulty in obtaining suitable specimens and keeping them at a low temperature during transit.

Specimens of faeces were collected from domiciliary patients and stored temporarily in the freezing compartment of a domestic refrigerator before deep freezing at the hospital. Specimens of cerebrospinal fluid were deep frozen at the hospital immediately after routine examination. Sera were stored at $-20^{\circ} \mathrm{C}$.

All specimens were kept frozen during transport to the laboratory, where faecal extracts were prepared, and these as well as specimens of cerebrospinal fluid were inoculated into HeLa cell and monkey kidney cell cultures in addition to mice less than 24 hours old.

Cell cultures were incubated at $37^{\circ} \mathrm{C}$. and observed for cytopathic changes on alternate days.

Material from cultures showing cytopathic changes was passed into fresh cultures. Cultures showing no change were discarded after 14 days.

Neutralization tests were performed on harvested fluids using antisera prepared against poliomyelitis virus types 1,2 and 3, Coxsackie B virus types 1 to 6 , and E.C.H.O virus type 9. The antisera were obtained from the Standards Laboratory for Serological Reagents, Colindale.

Inoculated litters of mice were examined at intervals for two weeks, but no illness was observed.

Complement-fixation tests were performed on specimens of serum using mumps virus particle and soluble antigens as well as lymphocytic choriomeningitis antigen. The method used was similar to that described by Bradstreet and Taylor (1962).

Neutralization tests for E.C.H.O virus type 9 were performed in the Virus Reference Laboratory, Colindale, on paired sera from five cases.

Agglutination tests for Leptospira icterohaemorrhagiae and canicola were also carried out.

\section{RESULTS}

The results of investigations are set out in Tables II and III. In addition to the haematological and

TABLE II

RESULTS OF VIRUS ISOLATIONS

$\begin{array}{ll}\text { No. of Specimens } & \text { No. of Strains of } \\ \text { Examined } & \text { Virus Type } 9\end{array}$ Isolated

\begin{tabular}{lrr}
\hline Faeces & 24 & 11 \\
Cerebrospinal fluid & 6 & 3
\end{tabular}


TABLE III

\begin{tabular}{|c|c|c|c|c|c|c|c|}
\hline & $\begin{array}{l}\text { ESULTS OF L } \\
\text { Case Number }\end{array}$ & $\begin{array}{l}\text { ABORATORY } \\
r\end{array}$ & TESTS IN IN & J-PATIENTS & & & \\
\hline & 1 & 2 & 3 & 4 & 5 & 6 & 7 \\
\hline Age in years & 6 & 9 & 4 & 11 & 3 & 9 & 12 \\
\hline $\begin{array}{l}\text { White blood cells } \\
\text { Total number } \\
\text { Polymorphs } \\
\text { Lymphocytes } \\
\text { Monocytes } \\
\text { Abnormal monocytes } \pm \\
\text { Eosinophils }\end{array}$ & $\begin{array}{l}13,000 \\
9,100(70 \%) \\
3,120(24 \%) \\
520(4 \%) \\
+\quad 260(2 \%)\end{array}$ & $\begin{array}{l}8,500 \\
7,140(84 \%) \\
765(9 \%) \\
510(6 \%) \\
85(1 \%)\end{array}$ & $\begin{array}{l}12,200 \\
8,052(66 \%) \\
2,196(18 \%) \\
1,220(10 \%) \\
732(6 \%) \\
0\end{array}$ & $\begin{array}{l}6,500 \\
4,500(70 \%) \\
1,950(30 \%) \\
0 \\
0\end{array}$ & $\begin{array}{l}18,900 \\
8,694(46 \%) \\
9,450(50 \%) \\
7,56(4 \%) \\
+\quad 0\end{array}$ & $\begin{array}{l}6,000 \\
3,240(54 \%) \\
2,580(43 \%) \\
180(3 \%) \\
\quad 0\end{array}$ & $\begin{array}{l}6,200 \\
4,092(66 \%) \\
1,860(30 \% \\
248(4 \%) \\
0\end{array}$ \\
\hline $\begin{array}{l}\text { E.S.R. } \\
\text { Cerebrospinal fluid }\end{array}$ & 32 & 18 & $\begin{array}{l}\text { Not } \\
\text { performed }\end{array}$ & $\begin{array}{l}\text { Not } \\
\text { performed }\end{array}$ & $\begin{array}{l}\text { Not } \\
\text { performed }\end{array}$ & 11 & 32 \\
\hline $\begin{array}{l}\text { Total cells } \\
\text { Polymorphs }(\%) \\
\text { Lymphocytes }(\%) \\
\text { Protein (mg. \%) } \\
\text { Globulin excess } \pm\end{array}$ & $\begin{array}{r}1,400 \\
95 \\
5 \\
94 \\
+\quad\end{array}$ & $\begin{array}{r}500 \\
25 \\
75 \\
45\end{array}$ & $\begin{array}{r}1,000 \\
35 \\
65 \\
44\end{array}$ & $\begin{array}{r}500 \\
21 \\
79 \\
32\end{array}$ & $\begin{array}{r}40 \\
5 \\
95 \\
40\end{array}$ & $\begin{array}{r}275 \\
30 \\
70 \\
29\end{array}$ & $\begin{array}{r}280 \\
28 \\
72 \\
70\end{array}$ \\
\hline Sugar (mg. \%) & 84 & 117 & 40 & 64 & 68 & 73 & $\begin{array}{l}\text { Not } \\
\text { performed }\end{array}$ \\
\hline Virus isolation on cerebrospinal fluid & $\begin{array}{l}\text { Not } \\
\text { performed }\end{array}$ & + & $\ldots \ldots$ & $\ldots \ldots$. & $\ldots . .$. & + & + \\
\hline Neutralizing titres of antibody in serum & ..... & $\begin{array}{l}\text { Not } \\
\text { performed }\end{array}$ & + & + & + & $\ldots .$. & $\ldots .$. \\
\hline $\begin{array}{l}\text { Neutralizing titres of antibody in serum } \\
\text { Acute }\end{array}$ & $1 / 8$ & $1 / 4$ & $1 / 64$ & $1 / 64$ & $1 / 4$ & $\begin{array}{l}\text { Not } \\
\text { performed }\end{array}$ & $\begin{array}{l}\text { Not } \\
\text { performed }\end{array}$ \\
\hline Convalescent & $1 / 8$ & $1 / 16$ & $1 / 64$ & $1 / 64$ & $1 / 8$ & $\begin{array}{l}\text { Not } \\
\text { performed }\end{array}$ & $\begin{array}{l}\text { Not } \\
\text { performed }\end{array}$ \\
\hline
\end{tabular}

cerebrospinal fluid examinations, all hospital cases had blood cultures, mid-stream specimens of urine, and throat swabs examined, but with negative results. Lumbar puncture was performed directly on the patient's admission to hospital, which was within 12 hours of the onset of severe headache, in all cases.

All the strains of E.C.H.O virus type 9 were isolated in monkey kidney cell cultures. No cytopathic effect was observed in $\mathrm{HeLa}$ cell cultures. The results of virus isolations from 43 cases investigated are shown in Table II.

Results of investigations on the cases admitted to hospital are shown in Table III.

Complement-fixation tests on paired sera for lymphotic choriomeningitis and mumps did not show any rising titres. Agglutination tests for Leptospira icterohaemorrhagiae and canicola were negative.

\section{DISCUSSION}

Two interesting features of the outbreak were first, the incidence of epistaxis in eight of 44 cases $(18 \%)$; second, the appearance of abnormal monocytes in

three out of seven cases which had haematologican investigations together with a raised absolut monocyte count in one case.

The raised cerebrospinal fluid cell counts and the raised peripheral total white blood cell counts hav $\overrightarrow{\vec{E}}$ been described previously (McNair Scott, 1961).

It is worth noting that the outbreak tended to decline at about the time when chlorination of the paddling pool was introduced. It is striking that no other case was seen at any other Royal Air Force unit despite frequent mixing of personnel.

We wish to thank the Director General of Medicab Services, Royal Air Force, for permission to publis this paper. I (C.R.N.) would also like to thank the senios medical officer and medical officers of the station concerned for their assistance in collecting clinical detaite and blood samples from the patients who were treated a home.

\section{REFERENCES}

Bradstreet, C. M. P., and Taylor, C. E. D. (1962). Mth. Bull. Minis Hlth Lab. Serv., 21, 96.

Lyle, W. H. (1959). Ann. intern. Med., 51, 248.

Sabin, A. B., Krumbiegel, E. R., and Wigand, R. (1958). Amer. J. Dis. Child., 96, 197.

Scott, T. F. McN. (1961). Advanc. Virus Res., 8, 165.

Tyrell, G. J. M. (1958). Quart. J. Med., 27, 323. 